\title{
Metal- and redox homeostasis in prostate cancer with vitamin $\mathrm{D}_{3}$ supplementation
}

\author{
Krisztina Süle ${ }^{\mathrm{a}, \mathrm{b}, *}$, Klára Szentmihályi ${ }^{\mathrm{a}}$, Gergó Szabób, Dénes Kleiner ${ }^{\mathrm{b}}$, Imre Varga ${ }^{\mathrm{c}}$, Anna Egresi ${ }^{\mathrm{b}}$, \\ Zoltán May ${ }^{\mathrm{a}}$, Péter Nyirády ${ }^{\mathrm{d}}$, Miklós Mohai Jr. ${ }^{\mathrm{e}}$, Anna Blázovics ${ }^{\mathrm{b}}$ \\ ${ }^{a}$ Institute of Materials and Environmental Chemistry, Research Centre for Natural Sciences of the Hungarian Academy of Sciences, Magyar Tudósok körútja 2, H-1117 \\ Budapest, Hungary \\ b Institute of Farmacognosy Semmelweis University, Üllói út 26, H-1086 Budapest, Hungary \\ ${ }^{\mathrm{c}}$ Medical Center of Dunakeszi, Fó út 75-86, H-2120 Dunakeszi, Hungary \\ d Department of Urology and Urooncological Centre, Semmelweis University, Üllôi út 78/b, H-1082 Budapest, Hungary \\ e Budapest University of Technology and Economics, Müegyetem rkp. 3, H-.1111 Budapest, Hungary
}

\section{A R T I C L E I N F O}

\section{Keywords:}

Micro-macro elements

prostate cancer

vitamin $\mathrm{D}_{3}$

ICP-OES

\begin{abstract}
A B S T R A C T
Vitamin $\mathrm{D}_{3}$ supplementation has a beneficial effect on cancerous patients, although it can influence the redoxand metal homeostasis. The aim of our investigation was to demonstrate the effect of vitamin $\mathrm{D}_{3}$ consumption on the redox- and metal homeostasis in prostate cancer, because of the recommended daily dose increased from 200 IU to $2000 \mathrm{IU}$ in recent years in Hungary. Forty-three volunteers were involved in the study. The grouping was applied according to the clinical routine laboratory parameters (vitamin $\mathrm{D}_{3}$ ) and the tumor markers (PSA, $f$ PFA). Patients were divided into 5 groups: (A) patient control $(\mathrm{N}=8)$, (B) patient control with vitamin $\mathrm{D}_{3}$ treatment $(\mathrm{N}=9)$, (C) high-risk prostate cancer group $(\mathrm{N}=6)$, (D) high-risk prostate cancer group with vitamin $\mathrm{D}_{3}$ treatment $(\mathrm{N}=8)$ and $(\mathrm{E})$ vitamin $\mathrm{D}_{3}$ treated cancerous group with androgen deprivation therapy $(\mathrm{N}=11)$. The element concentrations were determined with ICP-OES. Among the redox parameters, free radical scavenging capacity and H-donating ability were determined with luminometry and spectrometry. Vitamin $\mathrm{D}_{3}$ treatment caused differences in the metal- and redox homeostasis in either patient control and cancerous groups. The concentration of $\mathrm{Fe}, \mathrm{Cr}$, and $\mathrm{Pb}$ significantly increased in the erythrocytes of prostate cancer patients. According to the higher scavenging capacity by vitamin $D_{3}$ treatment, it seems that vitamin $D_{3}$ helps to equilibrate the redox homeostasis that could affect the outcome of cancer positively. However, the tendency in the metal element status does not give a clear explanation of cancer's outcome, but the accumulation of $\mathrm{Pb}$ by vitamin $\mathrm{D}_{3}$ supplementation needs to be taken into more serious consideration in set terms of occupational diseases.
\end{abstract}

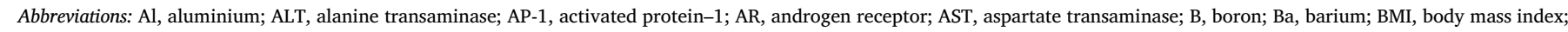

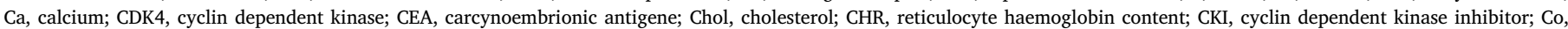

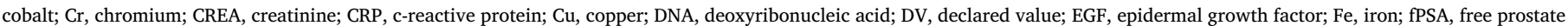

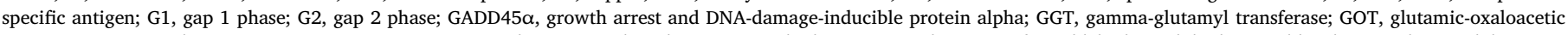

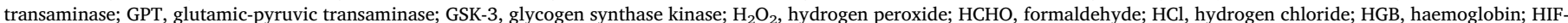

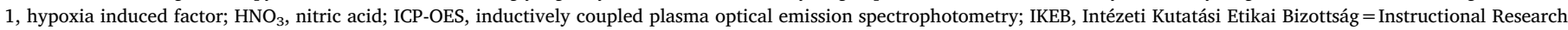

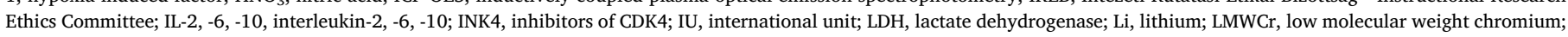

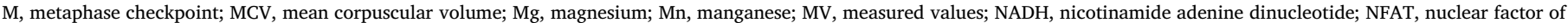

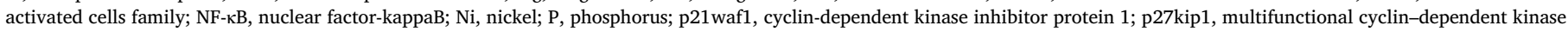

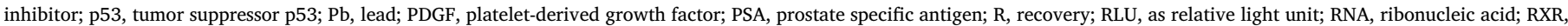

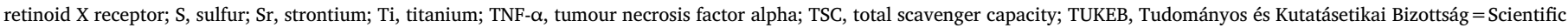
and Research Ethics Committee; UA, uric acid; V, vanadium; VDR, vitamin $\mathrm{D}_{3}$ receptor; VEGF, vascular endothelial growth factor; WBC, white blood cell; Zn, zinc

* Corresponding author at: Institute of Materials and Environmental Chemistry, Research Centre for Natural Sciences of the Hungarian Academy of Sciences, Magyar Tudósok körútja 2 , H-1117 Budapest, Hungary.

E-mail addresses: sule.krisztina@ttk.mta.hu (K. Süle), szentmihalyi.klara@ttk.mta.hu (K. Szentmihályi), szabo2gergo@gmail.com (G. Szabó), kleiner.denes@pharma.semmelweis-univ.hu (D. Kleiner), dkszakrend@gmail.com (I. Varga), egresi.anna@pharma.semmelweis-univ.hu (A. Egresi), may.zoltan@ttk.mta.hu (Z. May), nyirady.peter@med.semmelweis_univ.hu (P. Nyirády), mohaiv29@gmail.com (M. Mohai), blazovics.anna@pharma.semmelweis-univ.hu (A. Blázovics). 


\section{Introduction}

In the literature, there are a few investigations about the effect of vitamin $D_{3}$ against oxidative stress, but they show positive results, because vitamin $\mathrm{D}_{3}$ increases the SOD activity, reverses the alteration in the oxidative and nitrosative stress parameters [1]. Epidemiological studies indicate that vitamin $\mathrm{D}_{3}\left(1 \alpha, 25(\mathrm{OH})_{2} \mathrm{D}_{3}\right)$ deficiency is an important factor in various human cancer type [2-4]. In Europe, prostate cancer is one of the most commonly diagnosed malignant diseases among men after non-melanoma skin cancer, colorectal and lung cancer whose mortality increases with age. Besides genetic diversity and adverse environmental aspects, vitamin $\mathrm{D}_{3}$ deficiency plays an important role in the incidence of prostate cancer. Clinical researches and molecular studies have already established that vitamin $D_{3}$ inhibits cell proliferation on androgen receptor (AR)-positive and AR-negative in the prostate tumor cells. Antiproliferative effect of vitamin $D_{3}$ is mediated by the vitamin D receptor (VDR), as calcitriol $\left(1 \alpha, 25(\mathrm{OH})_{2} \mathrm{D}\right)$ binds to VDR, and it interacts with the retinoid X receptor (RXR) [5,6]. Several forms of cholecalciferol could be bound to the vitamin $D_{3}$ receptor, but 1,25-dihydroxycholecalciferol is biologically more potent due to its 1000 times higher affinity to VDR than that of to 25-hydroxycholecalciferol [7]. Nevertheless, a hormonally active form of vitamin $\mathrm{D}_{3}$ (25-dihydroxycholecalciferol) activates the apoptotic pathways through the expression of p53 tumor suppressor protein, modulates cell cycle by inhibition of the $\mathrm{G}_{1}-\mathrm{S}$ transition and inhibits cell differentiation in tumors through the signal transduction processes [8-10]. In vitro studies on human prostate cancer cell lines and mouse models have demonstrated that vitamin $\mathrm{D}_{3}$ and its derivatives can inhibit the growth of cancer cells, by inducing apoptosis and preventing cell proliferation [11-14]. Also, vitamin D secosteroids can activate cyclin-dependent kinase inhibitors, e.g. INK4 proteins, p21waf1, and p27kip1 [15].

With these findings, it is highly considered that the treatment of vitamin $\mathrm{D}_{3}$ and its analogs could be used as alternative therapy in prostate cancer.

There are still not enough indicators available to diagnose prostate cancer at an early stage and differentiate the patients who require prostatectomy or oncological treatment for healing. Even the level of prostate-specific antigen (PSA), whose height is the most common sign of the disease occurrence, can stay within the normal range or give a false negative result, especially at the early stage. Several studies were carried out to find a specific biomarker of the redox system to determine the disease severity. Some studies in human tumor cell lines refer to the increase of interleukins (IL-6, IL-10), tumor necrosis factor alpha (TNF- $\alpha$ ), VEGF signal protein, and the decrease of IL-2 in metastasis $[16,17]$. In one of our previous studies, the levels of cytokines and growth factors were lower at the early stage prostate cancer patients than the one in the controls. Furthermore, remarkable differences were found in the results of bound formaldehyde (HCHO), Zn-protoporphyrin and free protoporphyrin in erythrocytes of taxane-treated metastatic, histologically negative and positive patients compared to the healthy controls [18]. These findings are not only important in the process of DNA hypomethylation because it could lead to high mutation rate in most cases [19], but they are also in strong connection with the redox status [20].

On the other hand, it was also demonstrated that not only the metal elements could assist the absorption of vitamin $\mathrm{D}_{3}$ but conversely, the uptake of micro and macronutrients (e.g., $\mathrm{Ca}, \mathrm{Mg}, \mathrm{Cu}, \mathrm{Zn}, \mathrm{Fe}, \mathrm{Se}$ ), and certain transition metals might be facilitated by vitamin $D_{3}$ in the gastrointestinal tract in healthy individuals [21]. Even the absorption of heavy metals can be assisted by vitamin $D_{3}$. For that reason, despite the beneficial effects of vitamin $D_{3}$, heavy metal accumulation needs to be taken into account, since the absorption of non-essential metal elements could be affected by the vitamin $\mathrm{D}_{3}$ intake in human [22]. It was also demonstrated that the metal element status alters in the case of prostate cancer with special emphasis on the Pb level [23], but there is no study for investigating the metal element status in the function of vitamin $\mathrm{D}_{3}$ supplementation in prostate cancer.

Vitamin $\mathrm{D}_{3}$ deficiency could be a risk factor for prostate cancer in the Hungarian man population since the vitamin $\mathrm{D}_{3}$ is lower than the optimal level in $50 \%$ of the Hungarian population even in the summer period [24]. There is no information available in the literature about that how vitamin $\mathrm{D}_{3}$ treatment effects on the metal element and redox homeostasis in prostate cancer patients. Therefore, in the current study our aim was to perform a comprehensive investigation on how vitamin $\mathrm{D}_{3}$ supplementation in patient control and prostate cancer patients influences the metal element- and redox homeostasis after a three-year treatment.

\section{Materials and methods}

\subsection{Materials}

Vitamin $\mathrm{D}_{3}$ was a general consumer product on sale in the pharmacy. Each gelatine capsule contained 3000-3300 IU (75-82.5 $\mu \mathrm{g})$ cholecalciferol (vitamin $\mathrm{D}_{3}$ ). Standard solutions, nitric acid, and hydrogen chloride were purchased from Reanal (Budapest). 1,1-diphenyl2-picrylhydrazyl, stable radical, hydrogen peroxide, luminol, microperoxidase were obtained from Sigma (St. Luis). Spectro multi-element standard solutions were used for ICP (CPAchem; Stara Zagora, Bulgaria). The CHR hemoglobin reagent solution was purchased from Reagents Ltd., Hungary.

\subsection{Patients}

42 volunteers with a mean age of $62.1 \pm 15.9$ years were examined, of which 25 were the outpatients of the Medical Centre of Dunakeszi and 17 from the Department of Urology and Urooncological Centre at the Semmelweis University, Budapest Hungary. The grouping was executed by the treating physician according to cancer's progressivity (PSA, digital rectal examination, biopsy) and the vitamin $\mathrm{D}_{3}$ treatment. Harmful habits and other comorbidities of some patients (smoking, alcohol consumption, diabetes mellitus, another type of cancers) were considered. Conforming to the latter, two patients had to be excluded from the investigation. Patients with vitamin $D_{3}$ treated groups received vitamin $D_{3}$ treatment for three years continuously under strict physician control.

The diet of the patients didn't alter from the conventional Hungarian dietary, the intake of vitamin $\mathrm{D}_{3}$ was $2.5 \mu \mathrm{g} /$ day in men and $1.9 \mu \mathrm{g}$ /day in women of 35-64 years old, while Ca was $759 \mathrm{mg} /$ day in men and $690 \mathrm{mg} /$ day in women; $\mathrm{Cu}$ was $1.18 \mathrm{mg} /$ day in men and $0.94 \mathrm{mg} /$ day in women; and $\mathrm{Zn}$ was $9.65 \mathrm{mg} /$ day in men and $7.31 \mathrm{mg} /$ day in women [24]. According to their state, they were following a normal diet without taking any food supplements. The patients didn't work under extreme conditions and they weren't exposed to any metal toxicity (foundries, battery recycling, etc.). Blood samples were collected in spring (March-April) after the three-year treatment. The patients were divided into 5 groups according to the Table 1 :

Table 1

PSA level $(\mu \mathrm{g} / \mathrm{L})$ in different patients' groups after three-year treatment.

\begin{tabular}{ll}
\hline Patients & PSA $(\mu \mathrm{g} / \mathrm{L})$ \\
\hline Patient control group $(\mathrm{N}=8)$ & $1.11 \pm 0.45$ \\
Patient control group with vitamin $\mathrm{D}_{3}$ treatment $(\mathrm{N}=9)$ & $0.75 \pm 0.40$ \\
High-risk prostate cancer group $(\mathrm{N}=6)$ & $13.0 \pm 5.4^{*}$ \\
High-risk prostate cancer group with vitamin $\mathrm{D}_{3}(\mathrm{~N}=8)$ & $5.68 \pm 1.11^{*, * * *}$ \\
Vitamin $\mathrm{D}_{3}$ treated cancerous group with androgen & $1.40 \pm 2.44^{* * *}$ \\
$\quad$ deprivation therapy $(\mathrm{N}=11)$ & \\
\hline
\end{tabular}

* significant difference to the patient control $p<0.01$.

$* *$ significant difference to the high-risk prostate cancer without vitamin $\mathrm{D}_{3}$ treatment $p<0.01$. 
a patient control group ( $\mathrm{N}=8$ PSA $<2 \mu \mathrm{g} / \mathrm{L}$ ); a patient control group with vitamin $\mathrm{D}_{3}$ treatment $(\mathrm{N}=9$; PSA $<2 \mu \mathrm{g} / \mathrm{L})$; a high risk prostate cancer group $(\mathrm{N}=6$, PSA $>9 \mu \mathrm{g} / \mathrm{L})$; a high risk prostate cancer group with vitamin $\mathrm{D}_{3}$ treatment $(\mathrm{N}=8$; PSA $>4.1 \mu \mathrm{g} / \mathrm{L})$ and a cancerous group with vitamin $\mathrm{D}_{3}$ treatment who went under androgen deprivation therapy $(\mathrm{N}=11$, PSA $<9 \mu \mathrm{g} / \mathrm{L})$.

The prognosis of the prostate cancer was determined according to the PSA values, the digital rectal examination, and the biopsy results. Into the patient control group those patients were classified whose PSA value was under $2 \mu \mathrm{g} / \mathrm{L}$, their digital rectal examination didn't show any inflammation or benign enlargement on the prostate and who therefore weren't suggested to have further biopsy examination.

Into the high-risk prostate cancer group those patients were classified whose PSA value was higher than 2 , even higher than $4.1 \mu \mathrm{g} / \mathrm{L}$, furthermore, their digital rectal examination showed some inflammatory signs or enlargement on the prostate. They were also sent to biopsy but the results came out negative.

Patients, whose cancer condition was rated with a Gleason score, according to the anamnesis, were declared as the cancerous group. They were 1-2 stadium prostate cancer patients, their tumor didn't spread aggressively, and it didn't break through the tissue of the prostate. In their case, androgen deprivation therapy (Firmagon, Eligard, Bikalutam, Tamsulosin, Soladex, Differelin) was sufficient therefore chemotherapy, or radiotherapy was not necessarily needed.

\subsection{Vitamin $D_{3}$ dosage}

The 25-OH- $\mathrm{D}_{3}$ level in blood was adjusted by a therapist to about $100-150 \mathrm{nmol} / \mathrm{L}(40-60 \mathrm{ng} / \mathrm{mL})$. Each patient received individually 1000-9000 IU vitamin $\mathrm{D}_{3}$ in a daily intake. After determining the 25hydroxyvitamin $\mathrm{D}$ level in the blood, the patients continuously received the vitamin $\mathrm{D}_{3}$ treatment for three years before this study started. The ordered amount was determined according to the estimated BMI value and their health condition. The occasionally occurring vitamin $\mathrm{D}_{3}$ resistance was also taken into account. The most accurate adjustment of vitamin $\mathrm{D}_{3}$ level was achieved in the high-risk prostate cancer group (Table 2), due to the fresh diagnosis and the patient's better compliance with the vitamin $D_{3}$ treatment. In most cases, the routine parameters were normalized during the treatment, but unfortunately for $10-15 \%$ of the patients, there was no improvement, which can be due to the low VDR activity. In their case, Mg supplementation and a higher dose of vitamin $\mathrm{D}_{3}$ helped to bring vitamin $\mathrm{D}_{3}$ in their blood to a normal level. Further medical interventions would be needed in the cases of receptor disorders or vitamin $\mathrm{D}_{3}$ resistance. According to the body weight, medical treatment or other diseases, the vitamin $\mathrm{D}_{3}$ treatment was sustainable with daily $1000 \mathrm{IU}$ and rarely $9000 \mathrm{IU}$. Before the determination of the proper vitamin $\mathrm{D}_{3}$ dosage for each patient, the cholecalciferol level was measured in blood that was within 10-50 ng/ $\mathrm{mL}(25-125 \mathrm{nmol} / \mathrm{L})$. The study was accomplished in accordance with the ethical permissions, which was obtained from the Hungarian Medical Research Council (Permission number: TUKEB 167/1997. 15/ 2004) and the Institutional Review Board of the Semmelweis University (Permission number: IKEB 3944/2004.). According to the physiological

Table 2

$\mathrm{D}_{3}$ level (nmol/L) in patients' group after three-year treatment.

\begin{tabular}{ll}
\hline Patients & $\mathrm{D}_{3}$ vitamin level (nmol/L) \\
\hline Patient control group $(\mathrm{N}=8)$ & $74.3 \pm 12.3$ \\
Patient control group with vitamin $\mathrm{D}_{3}$ treatment & $99.2 \pm 31.5$ \\
$\quad(\mathrm{~N}=9)$ & $36.6 \pm 13.4$ \\
High-risk prostate cancer group $(\mathrm{N}=6)$ & $116 \pm 24$ \\
High-risk prostate cancer group with vitamin $\mathrm{D}_{3}$ & $133 \pm 80$ \\
$\quad(\mathrm{~N}=8)$ & \\
Vitamin $\mathrm{D}_{3}$ treated cancerous group with androgen & \\
$\quad$ deprivation therapy (N = 11) &
\end{tabular}

data under $5 \mathrm{ng} / \mathrm{ml}(12.5 \mathrm{nmol} / \mathrm{L})$ vitamin $\mathrm{D}_{3}$ level is considered to be deficient, between $10-20 \mathrm{ng} / \mathrm{mL}(25-50 \mathrm{nmol} / \mathrm{L})$ low and the normal range is between 28 and $80 \mathrm{ng} / \mathrm{mL}(70-200 \mathrm{nmol} / \mathrm{L})$ [25,26]. The vitamin $\mathrm{D}_{3}$ level was within the normal range in the vitamin $\mathrm{D}_{3}$ treated groups and the patient control group, but in the high-risk prostate cancer group $(\mathrm{N}=6)$ without vitamin $\mathrm{D}_{3}$ treatment it was in the low range (Table 2).

\subsection{Preparation of blood samples}

After three-year treatment blood samples were collected in $3.2 \%$ sodium citrate anticoagulant Vacutainer tubes (Greiner Bio-One, Hungary of Vacutainer, USA) and were stored at $4^{\circ} \mathrm{C}$. They were prepared with standard routine laboratory methods. The erythrocytes were separated from plasma and buffy coat by centrifugation at $2500 \mathrm{rpm}$ for $10 \mathrm{~min}$. The separation of the blood was started within $1.5 \mathrm{~h}$ after blood collection. The buffy coat suspension was removed from the blood to avoid its bias effect while activating free radical reactions. Subsequently, the erythrocyte was washed with isotonic saline solution twice, and $20 \mu \mathrm{l}$ of the raw fraction was standardized to $1 \%$ hemoglobin with CHR Haemoglobin reagent. For hemoglobin determination, the absorbance was measured at $540 \mathrm{~nm}$ on a Hitachi U-2000 spectrophotometer. After blood separation and hemoglobin standardization process the redox parameter measurements and the metal element analysis were started.

\subsection{Measurement of routine laboratory parameters}

The laboratory parameters (hematology, immunochemical parameters, tumor markers) were measured by Synlab Hungary Kft, after the three-year treatment when the blood was taken. The monitoring of the vitamin $\mathrm{D}_{3}$ treatment was accomplished by the measurement of 25$(\mathrm{OH}) \mathrm{D}_{3}$ vitamin/cholecalciferol in sera among the laboratory parameters. The determination of routine laboratory parameters was performed with automatized laboratory instruments in ISO 9001:2008 environment. The following laboratory parameters were measured in blood: glutamic-oxaloacetic transaminase/aspartate transaminase (AST/GOT), glutamic-pyruvic transaminase/alanine transaminase (ALT/GPT), gamma-glutamyl transferase (GGT), uric acid (UA), cholesterol (Chol), creatinine (CREA), lactate dehydrogenase (LDH), haemoglobin (HGB), mean corpuscular volume (MCV), C-reactive protein (CRP), prostate-specific antigen (PSA), free prostate specific antigen (fPSA), white blood cell (WBC). Carcinoembryonic antigen (CEA) was measured from serum with LIA-Mat immuno-luminometry (Budapest) kits.

Most of the laboratory parameters were within the normal range, and there were no significant differences between the groups, which can be due to the adequate medical treatment. Therefore these data were omitted from the results part. There was no remarkable difference in the cancerous groups in the liver parameters (GGT, GOT, GPT), creatinine and MVC parameters. Cholesterol and leukocyte were $14 \%$ and $20 \%$ higher in the high-risk cancerous group without vitamin $\mathrm{D}_{3}$ treatment, and triglyceride was $33 \%$ higher in the vitamin $\mathrm{D}_{3}$ treated high-risk cancerous group compared to the control. The level of CRP and CEA should give information about inflammation or the presence of tumor in the body. Despite that in our result, the value of CRP and CEA didn't exceed the normal level, and neither was much difference between groups which can be due to the patients' appropriate treatment.

The PSA level should be considered abnormal above $4.1(\mu \mathrm{g} / \mathrm{L})$. In the high-risk prostate cancer group who didn't receive either vitamin $\mathrm{D}_{3}$ or androgen deprivation therapy, the PSA level was significantly high compared to the vitamin $D_{3}$ treated group of which PSA value was closer to the normal range but still high (Table 1). In these groups, the digital rectal examination showed the mutation in the prostate size and density, but the biopsy examination came out with negative results. 


\subsection{Measurement of redox parameters}

The hydrogen-donating ability in plasma was estimated in the presence of 1,1-diphenyl-2-picrylhydrazyl radical according to the method of Hatano et al. [27] using Hitachi U-2000 spectrophotometer. The results of the $\mathrm{H}$-donating ability was calculated in inhibition percentage (Inhib\%). Induced chemiluminescence of the plasma and erythrocytes was measured by a luminol-dependent chemiluminescence assay $\left(\mathrm{H}_{2} \mathrm{O}_{2} / \mathrm{OH}\right.$-microperoxidase-luminol-based system) according to the method of Blázovics et al. [28]. This method was adapted to a Berthold Lumat 9501 manual instrument (Berthold GmbH, Germany) [29]. The results had been expressed as a relative light unit percentage (RLU\%) that is inversely proportional to the degree of scavenging capacity.

\subsection{Measurements of micro and macro element concentration}

The separated erythrocyte samples were measured on analytic balance then they were digested in the mixture of $10 \mathrm{ml}$ of $\mathrm{HNO}_{3}(65 \%)$, $2 \mathrm{ml} \mathrm{HCl}(37 \%)$ and $4 \mathrm{ml} \mathrm{H}_{2} \mathrm{O}_{2}(30 \%)$. The procedure was performed on $200{ }^{\circ} \mathrm{C}$ in block digester. The blind was prepared under the same condition. After digestion of the samples, they were diluted with ion exchange water (17 M $\Omega, 28^{\circ} \mathrm{C}$; Purelab Ultra MK2. ULXXXIOM2 Model) to $25 \mathrm{ml}$. Measurements were performed with a Spectro Genesis simultaneous ICP-OES spectrometer equipped with CCD detector (Kleve, Germany) and axial plasma viewing [30].

The metal element concentrations in the bovine liver as Certified Reference Material (Institute for Reference Materials and Measurements, BCR $^{\circ}$-185R) were determined for the demonstration of reliability and precision of the measurement (Table 3 ). The recovery (R) was calculated from the declared (DV) and measured values (MV) as follows: $\mathrm{R}=\mathrm{MV} / \mathrm{DV} * 100$. In the case of most elements, which had no certified values, the repeatability measurements were performed (five times) with standard solutions of $0.5 \mu \mathrm{g} / \mathrm{mL}, 5 \mu \mathrm{g} / \mathrm{mL}$, and $10 \mu \mathrm{g} / \mathrm{mL}$ concentrations, and the recovery was calculated from these results (Table 3).

\subsection{Statistical analysis}

The basic statistical analysis was prepared using Microsoft Office Excel 2016 and Statistica 12 (StatSoft Inc., Tulsa. USA) software. To

Table 3

Element concentration in reference material (Bovine liver Certified Reference Material, BCR ${ }^{\circ}-185 R$ ) and standard solution, as well as the measured values with their recovery data.

\begin{tabular}{lllll}
\hline Elements & $\begin{array}{l}\text { Certified } \\
\text { value } \\
(\mu \mathrm{g} / \mathrm{g})\end{array}$ & $\begin{array}{l}\text { Concentration of } \\
\text { standard solution }(\mu \mathrm{g}) \\
\mathrm{mL})\end{array}$ & $\begin{array}{l}\text { Measured value } \\
(\mu \mathrm{g} / \mathrm{g} \text { and } \mu \mathrm{g} / \mathrm{mL}) \\
(\mathrm{N}=5)\end{array}$ & $\begin{array}{l}\text { Recovery } \\
(\%)\end{array}$ \\
\hline $\mathrm{Al}$ & & 0.5 & $0.502 \pm 0.002$ & 100 \\
$\mathrm{~B}$ & & 0.5 & $0.503 \pm 0.006$ & 101 \\
$\mathrm{Ba}$ & & 0.5 & $0.501 \pm 0.002$ & 100 \\
$\mathrm{Ca}$ & & 10 & $9.99 \pm 0.04$ & 99.9 \\
$\mathrm{Cd}$ & 0.544 & & $0.534 \pm 0.027$ & 98.2 \\
$\mathrm{Co}$ & & 0.5 & $0.500 \pm 0.002$ & 100 \\
$\mathrm{Cr}$ & & 0.5 & $0.497 \pm 0.001$ & 97.5 \\
$\mathrm{Cu}$ & 277 & & $279 \pm 6$ & 99.4 \\
$\mathrm{Fe}$ & & 10 & $9.99 \pm 0.04$ & 99.9 \\
$\mathrm{Li}$ & & 0.5 & $0.501 \pm 0.005$ & 100 \\
$\mathrm{Mg}$ & & 0.5 & $0.510 \pm 0.002$ & 102 \\
$\mathrm{Mn}$ & 11.07 & & $10.8 \pm 0.6$ & 97.6 \\
$\mathrm{Ni}$ & & 0.5 & $0.498 \pm 0.006$ & 99.6 \\
$\mathrm{P}$ & & 50 & $49.9 \pm 0.5$ & 99.8 \\
$\mathrm{~Pb}$ & 0.172 & & $0.171 \pm 0.006$ & 99.4 \\
$\mathrm{~S}$ & & 50 & $50.5 \pm 0.6$ & 101 \\
$\mathrm{Sr}$ & & 0.5 & $0.502 \pm 0.003$ & 100 \\
$\mathrm{Ti}$ & & 10 & $9.99 \pm 0.052$ & 99.9 \\
$\mathrm{~V}$ & & 0.5 & $0.498 \pm 0.007$ & 99.6 \\
$\mathrm{Zn}$ & 138.6 & & $140 \pm 6$ & 101 \\
\hline & & & & \\
\hline
\end{tabular}

verify distribution, Shapiro-Wilks test was used. The data had nonparametric distribution. Therefore Mann-Whitney $U$ test was used for the comparison of groups. The significance level was determined at $p<0.01$. To calculate the correlation between data Spearman's rank correlations were used as they are more appropriate for not normal distribution data than a linear correlation (e.g Pearson). Significant correlations were determined at $p<0.05$.

\section{Results}

There are significant differences between the mean values of essential and non-essential element concentrations measured in the treated and non-treated groups as it is shown in Table 4. Interestingly, the concentration of $\mathrm{Pb}$ was higher in the vitamin $\mathrm{D}_{3}$ treated patient control and diseased groups than that of in the non-treated groups. The difference was significant $(p<0.01)$ between the vitamin $\mathrm{D}_{3}$ treated cancerous group and the non-treated high-risk cancerous patients. Similar tendency could be observed in the Ca concentration, which was also elevated in the vitamin $\mathrm{D}_{3}$ treated groups compared to the groups without vitamin $\mathrm{D}_{3}$ administration. In addition, the Ca concentration level in the vitamin $\mathrm{D}_{3}$ treated high-risk cancerous and cancerous groups approached the control value. A significant difference $(p<0.01)$ could be observed between the vitamin $D_{3}$ supplemented patient control individuals compared to the control group.

The study also demonstrates that the $\mathrm{Cr}(p<0.01)$ level was significantly higher in the vitamin $\mathrm{D}_{3}$ treated patient control and diseased groups than that of in the groups without vitamin $\mathrm{D}_{3}$ administration.

Other metal elements such as $\mathrm{B}, \mathrm{Co}, \mathrm{Fe}, \mathrm{Mg}, \mathrm{Mn}, \mathrm{Ti}, \mathrm{V}$, and $\mathrm{Zn}$ represented a similar tendency to the previous results, with higher concentration in the vitamin $\mathrm{D}_{3}$ treated patient control and cancerous groups. The Fe, Mg, Mn and $\mathrm{Zn}$ concentrations were remarkably higher in the vitamin $\mathrm{D}_{3}$ treated groups compared to the non-treated ones. In the Fe level significant difference $(p<0.01)$ was found between the cancerous group with vitamin $\mathrm{D}_{3}$ treatment and the non-treated highrisk cancerous group (Table 4$)$. The concentration of $\mathrm{Ni}, \mathrm{Ca}, \mathrm{Cr}$ seemed to be significantly higher $(p<0.01)$ in the patient control group with vitamin $\mathrm{D}_{3}$ administration than that of in the patient control without treatment.

The concentration of $\mathrm{Cu}$ and $\mathrm{Li}$ showed the opposite tendency to the previously mentioned metals because in the vitamin $\mathrm{D}_{3}$ treated patient control and diseased groups the concentration of $\mathrm{Cu}$ and $\mathrm{Li}$ was lower than that of in the non-treated ones. A significant difference was found in the $\mathrm{Cu}$ concentration $(p<0.01)$ between the high-risk cancerous group and the vitamin $\mathrm{D}_{3}$ treated cancerous group who received androgen deprivation therapy. The results also present that, despite the lower $\mathrm{Cu}$ concentration in the vitamin $\mathrm{D}_{3}$ treated groups; its level is close to the control value in the vitamin $\mathrm{D}_{3}$ treated high-risk prostate cancer group (Table 4), as it was also observed by the Ca concentration.

In the results of the redox parameters measured in plasma, a lower value (RLU\%) could be observed in the vitamin $D_{3}$ treated patient control group compared to the non-treated patient control, which reflects higher scavenging capacity in the supplemented group (Table 5). That difference was more pronounced in the cancerous and high-risk cancerous groups while the RLU\% results were lower and the RLU\% in the cancerous group was significantly lower, compared to the nontreated high-risk cancer group, which indicates higher scavenging capacity in the treated groups. In erythrocyte, the induced chemiluminescence was found to have an opposite tendency to the plasma results. In the vitamin $D_{3}$ treated groups the RLU\% results were higher than that of in the control group, which implies low free radical scavenging capacity in patient control and diseased groups too. The difference was significant $(p<0.01)$ between the vitamin $\mathrm{D}_{3}$ treated diseased groups and the non-treated high-risk cancerous group (Table 5).

The outcome of the results of the H-donating ability in plasma was higher in the vitamin $\mathrm{D}_{3}$ treated groups both in patient control and prostate cancer patients (Table 5), as it was expected from the 
Table 4

Metal element concentration \pm standard deviation $(\mu \mathrm{g} / \mathrm{g})$ in erythrocyte after three-year treatment.

\begin{tabular}{|c|c|c|c|c|c|}
\hline Elements & $\begin{array}{l}\text { Patient control group } \\
(\mathrm{N}=8)\end{array}$ & $\begin{array}{l}\text { Patient control group with } \\
\text { vitamin } \mathrm{D}_{3} \text { treatment }(\mathrm{N}=9)\end{array}$ & $\begin{array}{l}\text { High-risk prostate cancer } \\
\text { group }(\mathrm{N}=6)\end{array}$ & $\begin{array}{l}\text { High-risk prostate cancer group } \\
\text { with vitamin } \mathrm{D}_{3}(\mathrm{~N}=8)\end{array}$ & $\begin{array}{l}\text { Vitamin } \mathrm{D}_{3} \text { treated cancerous group with } \\
\text { androgen deprivation therapy }(\mathrm{N}=11)\end{array}$ \\
\hline $\mathrm{Al}$ & $<0.058$ & $<0.058$ & $<0.058$ & $<0.058$ & $<0.058$ \\
\hline B & $4.57 \pm 5.89$ & $6.18 \pm 3.106$ & $2.39 \pm 2.42$ & $7.04 \pm 1.97$ & $9.39 \pm 5.05$ \\
\hline $\mathrm{Ba}$ & $0.447 \pm 0.273$ & $0.245 \pm 0.172$ & $0.316 \pm 0.311$ & $0.115 \pm 0.149$ & $0.113 \pm 0.136$ \\
\hline $\mathrm{Ca}$ & $2.84 \pm 2.36$ & $4.32 \pm 0.99^{*}$ & $2.44 \pm 1.91$ & $2.94 \pm 1.79$ & $3.32 \pm 1.46$ \\
\hline Co & $<0.004$ & $0.057 \pm 0.024$ & $<0.004$ & $0.012 \pm 0.01$ & $0.005 \pm 0.002$ \\
\hline $\mathrm{Cr}$ & $0.044 \pm 0.029$ & $0.101 \pm 0.056^{*}$ & $0.026 \pm 0.015$ & $0.097 \pm 0.025^{* *}$ & $0.097 \pm 0.038^{* *}$ \\
\hline $\mathrm{Cu}$ & $0.054 \pm 0.048$ & $0.021 \pm 0.014$ & $0.080 \pm 0.042$ & $0.043 \pm 0.060$ & $0.027 \pm 0.025^{* *}$ \\
\hline $\mathrm{Fe}$ & $29.0 \pm 4.9$ & $35.0 \pm 5.1$ & $24.8 \pm 5.9$ & $37.2 \pm 3.9$ & $34.9 \pm 3.4^{k * *}$ \\
\hline $\mathrm{Li}$ & $0.106 \pm 0.087$ & $0.006 \pm 0.004$ & $0.113 \pm 0.061$ & $0.007 \pm 0.003$ & $0.007 \pm 0.004$ \\
\hline $\mathrm{Mg}$ & $1.67 \pm 0.30$ & $2.03 \pm 1.04$ & $1.29 \pm 0.49$ & $1.74 \pm 0.28$ & $1.74 \pm 0.52$ \\
\hline $\mathrm{Mn}$ & $0.011 \pm 0.007$ & $0.033 \pm 0.065$ & $0.010 \pm 0.010$ & $0.013 \pm 0.012$ & $0.015 \pm 0.015$ \\
\hline $\mathrm{Ni}$ & $0.051 \pm 0.026$ & $0.150 \pm 0.050^{*}$ & $0.461 \pm 0.500$ & $0.170 \pm 0.109$ & $0.248 \pm 0.304$ \\
\hline $\mathrm{P}$ & $14.1 \pm 3.6$ & $10.7 \pm 2.7$ & $12.1 \pm 3.3$ & $12.5 \pm 3.3$ & $10.5 \pm 2.9$ \\
\hline $\mathrm{Pb}$ & $0.132 \pm 0.046$ & $0.197 \pm 0.129$ & $0.131 \pm 0.053$ & $0.723 \pm 0.919$ & $1.36 \pm 0.78^{* *}$ \\
\hline$S$ & $54.9 \pm 1.7$ & $51.3 \pm 5.3$ & $54.3 \pm 2.8$ & $55.2 \pm 6.0$ & $50.8 \pm 4.2$ \\
\hline $\mathrm{Sr}$ & $0.027 \pm 0.013$ & $0.021 \pm 0.033$ & $0.023 \pm 0.012$ & $0.010 \pm 0.014$ & $0.012 \pm 0.011$ \\
\hline $\mathrm{Ti}$ & $0.072 \pm 0.069$ & $0.776 \pm 1.083$ & $<0.004$ & $0.216 \pm 0.174$ & $0.236 \pm 0.294$ \\
\hline $\mathrm{V}$ & $<0.031$ & $0.047 \pm 0.032$ & $<0.031$ & $0.042 \pm 0.011$ & $0.046 \pm 0.011$ \\
\hline $\mathrm{Zn}$ & $0.372 \pm 0.082$ & $0.518 \pm 0.259$ & $0.307 \pm 0.132$ & $0.521 \pm 0.173$ & $0.436 \pm 0.215$ \\
\hline
\end{tabular}

* significant difference to the patient control $p<0.01$.

$* *$ significant difference to the high risk prostate cancer without vitamin $\mathrm{D}_{3}$ treatment $p<0.01$.

scavenging capacity results.

\section{Discussion}

Vitamin $\mathrm{D}_{3}$ is an important vitamin for treatment against prostate cancer due to its probable protective effect against tumorigenesis $[9,10,31,32]$. In this study, the effect of vitamin $D_{3}$ on prostate cancer and its effect on the metal element- and redox homeostasis in patient control and diseased individuals were studied.

The PSA results (Table 1 ) show low values in the vitamin $\mathrm{D}_{3}$ treated patient control and diseased groups. The vitamin $\mathrm{D}_{3}$ level (Table 2) and the induced chemiluminescence in plasma (Table 5) show an adverse tendency that might refer to free radical scavenging contribution of vitamin $\mathrm{D}_{3}$.

Significantly higher $\mathrm{Pb}$ concentration was found in the vitamin $\mathrm{D}_{3}$ treated cancerous groups compared to the non-treated groups. In early and advanced stage prostate cancer other heavy metals tend to accumulate which was established by other investigations as well [33]. So far there are only a few studies that deal with the interaction between vitamin $\mathrm{D}_{3}$ and $\mathrm{Pb}$. Although, Ca absorption and metabolism are closely associated with vitamin $D_{3}$ [34] since $C a$ and vitamin $D_{3}$ interacts in many enzymatic pathways as it has a regulatory role in the Ca metabolism. Ca uptake is stimulated by vitamin $\mathrm{D}_{3}$ [35] and Ca is built into the bone's structure with the intervention of vitamin $D_{3}$ [36]. One would expect that in all treated groups the level of Ca should be increased in red blood cells, but in this experiment Ca level was significantly elevated only in the patient control group. The large standard deviation can be explained by the patients' diverse eating habits. This result needs to awake more attention while the high Ca concentration in the healthy body might lead to hypercalcemia which is among the adverse consequences of vitamin $\mathrm{D}_{3}$ overdose.

The metabolism of $\mathrm{Ca}$ and $\mathrm{Pb}$ relates at many points in their homeostasis, and they compete for the same calcium binding sites [37-39]. It is known that $\mathrm{Pb}$ has a greater affinity to calcium binding proteins. Therefore small quantities of $\mathrm{Pb}$ can replace $\mathrm{Ca}$ [40]. Although, the interaction between $\mathrm{Pb}$ and vitamin $\mathrm{D}_{3}$ biosynthesis is underway to be clarified [38], $\mathrm{Pb}$ accumulation in the erythrocyte is suspected to effect on vitamin $\mathrm{D}_{3}$ metabolism. It has been scientifically proven that the controlled concentration of metals is essential for the normal function of the enzymes and transcription factors.

Higher $\mathrm{Cu}$ level, as well as lower Fe and $\mathrm{Zn}$ concentration, were detected in early-stage prostate cancer patients who didn't receive vitamin $\mathrm{D}_{3}$ or androgen deprivation treatment compared to the control group that is in agreement with some studies in the literature of prostate cancer patients [41,42]. The metal element homeostasis change in cancer refers to different essential microelements and heavy metal status in the body. The abnormally elevated level of heavy metals and the accumulation or deficiency of some essential transition metals such as $\mathrm{Co}, \mathrm{Cu}$, and $\mathrm{Fe}$, could also be a responsible factor for the impairment of receptor functions and enzymes activity such as tyrosine kinases [43]. It adversely affects signal molecules such as EGF, PDGF, VEGF, NF-кB, AP-1, p53, NFAT and HIF-1 [44]. Fe deficiency can be a reason for anemia in cancer [45]. These metal elements showed higher concentration in the vitamin $\mathrm{D}_{3}$ treated groups in the recent study. However, the level of Fe was elevated in the vitamin $D_{3}$ treatment both in patient control and diseased individuals, this result strengthens an

Table 5

Redox parameters in erythrocyte after three-year treatment.

\begin{tabular}{|c|c|c|c|}
\hline Patients & $\begin{array}{l}\text { Induced chemiluminescence in plasma } \\
\text { (RLU\%) }\end{array}$ & $\begin{array}{l}\text { Induced chemiluminescence in erythrocyte } \\
\text { (RLU\%) }\end{array}$ & $\begin{array}{l}\text { H-donating ability } \\
\text { in plasma } \\
\text { (inhibition\%) }\end{array}$ \\
\hline Patient control group $(\mathrm{N}=8)$ & $144 \pm 157$ & $144 \pm 46$ & $63.6 \pm 12.5$ \\
\hline Patient control group with vitamin $\mathrm{D}_{3}$ treatment $(\mathrm{N}=9)$ & $105 \pm 122$ & $177 \pm 39$ & $72.0 \pm 4.2$ \\
\hline High-risk prostate cancer group $(\mathrm{N}=6)$ & $217 \pm 179$ & $125 \pm 23$ & $62.8 \pm 14.0$ \\
\hline High-risk prostate cancer group with vitamin $\mathrm{D}_{3}(\mathrm{~N}=8)$ & $71 \pm 40$ & $156 \pm 57^{* * *}$ & $75.5 \pm 12.5^{* *}$ \\
\hline $\begin{array}{l}\text { Vitamin } D_{3} \text { treated cancerous group with androgen deprivation } \\
\text { therapy }(\mathrm{N}=11)\end{array}$ & $71 \pm 49^{* k t k}$ & $170 \pm 70^{* k *}$ & $69.2 \pm 9.9$ \\
\hline
\end{tabular}

** significant difference to the high-risk prostate cancer without vitamin $\mathrm{D}_{3}$ treatment $p<0.01$. 
earlier experiment that vitamin $\mathrm{D}_{3}$ is needed to administer Fe uptake into red blood cells [46]. Zn metabolism is specific in prostate cancer since in malign prostate cells $\mathrm{Zn}$ level was found to be significantly low [47-49] and it has been established that $\mathrm{Zn}$ depletion in the prostate's peripheral zone correlates with the Gleason score [33]. The higher Zn level can be favorable since $\mathrm{Zn}$ is an important microelement in the immune processes by protecting the erythrocytes against oxidative stress [50]. However, the high ratio of $\mathrm{Zn} / \mathrm{Fe}$ can assist the red blood cells against the free radical load in prostate cancers progression. In our results, the $\mathrm{Zn} / \mathrm{Fe}$ ratio was reduced in the early stage prostate cancer group who did not receive any treatment, however in the vitamin $D_{3}$ treated patient control group and high-risk cancerous groups the $\mathrm{Zn} / \mathrm{Fe}$ ratio was higher, that was caused by the higher $\mathrm{Zn}$ concentration in the erythrocyte. Significantly elevated Zn-protoporphyrin concentration can be observed in erythrocytes in cancerous processes which is very important in cancer-associated anemia.[51].

The patients who received vitamin $\mathrm{D}_{3}$ treatment had significantly high $\mathrm{Cr}$ level both in patient control and diseased population. In the literature so far there were very few investigations about the role of $\mathrm{Cr}$ in prostate cancer or the importance of vitamin $\mathrm{D}_{3}$ in the Cr metabolism, however, in our results, the significant differences are shown between the treated and non-treated groups. $\mathrm{Cr}$ is an important factor in the glucose metabolism through a low molecular weight chromium (LMWCr)-binding substance [52]. As it is already established that glucose induces cell proliferation in prostate cancer [53], our result should bring up more questions about the effect of $\mathrm{Cr}$ in prostate cancer and of vitamin $\mathrm{D}_{3}$ on $\mathrm{Cr}$ metabolism.

There are some non-significant changes for elements nevertheless their tendency can show valuable information. For example, the level of $\mathrm{Mg}$ was elevated in the vitamin $\mathrm{D}_{3}$ treated groups which are in accordance with previous studies, where increased $\mathrm{Mg}$ absorption was observed after a pharmacological dose of vitamin $\mathrm{D}_{3}$ supplementation $[54,55]$. However, $\mathrm{Mg}$ also effects on vitamin $\mathrm{D}_{3}$ metabolism that enables binding to the vitamin $\mathrm{D}_{3}$ transporter protein and facilitates the hydroxylation of vitamin $D_{3}$ to be converted into its active form in the liver and kidney [56]. Nevertheless, the role of $\mathrm{Mg}$ in prostate cancer needs further investigations.

Ni concentration was high in the untreated high-risk prostate cancer group but in the vitamin $\mathrm{D}_{3}$ treated and the control groups the $\mathrm{Ni}$ concentration was low. The role of $\mathrm{Ni}$ in prostate cancer and of vitamin $\mathrm{D}_{3}$ in Ni metabolism hasn't been clarified yet. According to the literature, the competition between $\mathrm{Ni}$ and $\mathrm{Mg}$ in the DNA repair mechanism has been already discovered [54,57], but there are still no results investigating the interaction of these two metals in prostate cancer and how vitamin $D_{3}$ has an influence on their metabolism in normal or even in diseased conditions. According to our results, there might be a connection in the metabolism of the vitamin $\mathrm{D}_{3}$ and $\mathrm{Ni}$, that could be beneficial, as Ni concentration approaches the control values that could also be observed by $\mathrm{Ca}, \mathrm{Cu}, \mathrm{Mn}$ and $\mathrm{Mg}$ values too.

It seems from our results that in the groups with vitamin $\mathrm{D}_{3}$ treatment the Li level was lower in erythrocyte. This could be a dangerous side effect as Li deficiency can lead to neurologic diseases [58] through the inhibition of the signal transduction of phosphoinositide cycle by reducing the cellular level of inositol which is linked to memory impairment and depression [59]. Li may protect against oxidative stress, which occurs during neurologic defects, by up-regulating the NADH dehydrogenase and the cytochrome b-c1 complexes of the mitochondrial electron transport chain [59]. There is little data available in the literature about the role of $\mathrm{Li}$ in prostate cancer. Its anti-cancer potential was investigated and it was established that Li inhibits the glycogen synthase kinase 3 (GSK-3) action, that's activation is associated with the prostate cancer's progression [60].

We found lower induced chemiluminescence in the plasma (Table 5) of vitamin $\mathrm{D}_{3}$ treated patient control and cancerous individuals compared to the patient control and cancerous group without treatment that could refer to higher free radical scavenging capacity in those groups. The results of redox parameters allow us to suppose that the permanent vitamin $\mathrm{D}_{3}$ intake affects the redox homeostasis through its metabolism in the diseased environment and normal conditions, too. The differences between patient control groups with and without vitamin $D_{3}$ administration proposes the question whether the persistent treatment of vitamin $\mathrm{D}_{3}$ is necessary with the current instructions. Normally, in cancer, the free radical scavenging capacity is lower than that of in the control groups, and it is usually elevated in the final stage of metastasis [61] that may show a connection to the vitamin $\mathrm{D}_{3}$ deficiency that could lead to the activation of glutathione-dependent enzymes [62].

The elevation of the inhibition\% in plasma might be due to the indirect concentration growth of those molecules which have an $\mathrm{H}$ donating capacity. It is assumed that vitamin $\mathrm{D}_{3}$ treatment has a potential role in the inflammatory suppression processes.

The oxidative stress induction by the extended concentration of certain metal elements is known and it is agreed with our results. The free scavenging capacity in erythrocytes was lower in the groups where a high concentration of $\mathrm{Fe}, \mathrm{Pb}$ and $\mathrm{Cr}$ could be observed. Decreased $\mathrm{Zn} /$ Fe ratio could be observed in the groups with high RLU\%. The concentration of $\mathrm{Zn}$ was elevated in the groups where the antioxidant capacity was high. From the literature, it is already known that $\mathrm{Zn}$ assists the immune strengthening processes that is possibly related to the higher scavenging capacity and facilitates the absorption of vitamin $\mathrm{D}_{3}$ [63].

Significantly positive $(p<0.05)$ correlations were found between

Table 6

Significant correlation values (Spearman's rank correlation coefficient) between the metal elements and redox parameters or PSA; and between the vitamin $\mathrm{D}_{3}$ level and metal elements measured from erythrocyte $(p<0.05)$.

\begin{tabular}{llllll} 
& $\begin{array}{l}\text { Patient control } \\
\text { group (N=8) }\end{array}$ & $\begin{array}{l}\text { Patient control group with } \\
\text { vitamin } \mathrm{D}_{3} \text { treatment }(\mathrm{N}=9)\end{array}$ & $\begin{array}{l}\text { High-risk prostate } \\
\text { cancer group }(\mathrm{N}=6)\end{array}$ & $\begin{array}{l}\text { High-risk prostate cancer } \\
\text { group with vitamin } \mathrm{D}_{3} \\
(\mathrm{~N}=8)\end{array}$ & $\begin{array}{l}\text { Vitamin } \mathrm{D}_{3} \text { treated cancerous group with } \\
\text { androgen deprivation therapy }(\mathrm{N}=11)\end{array}$ \\
\hline $\begin{array}{l}\text { PSA-Fe } \\
\text { PSA-Mg }\end{array}$ & 0.866 & & 0.904 \\
$\begin{array}{l}\text { PSA-Sr } \\
\text { (RLU\%) erythrocyte-Ba }\end{array}$ & -0.809 & 0.866 & & -0.813 \\
$\begin{array}{l}\text { (RLU\%) erythrocyte-Cu } \\
\text { (RLU\%) erythrocyte-Li }\end{array}$ & -0.762 & & -0.667 & -0.673 \\
$\begin{array}{l}\text { (RLU\%) erythrocyte- } \\
\text { Mg }\end{array}$ & & & -0.775 \\
$\begin{array}{l}\text { (RLU\%) erythrocyte- } \\
\text { Mn }\end{array}$ & 0.711 & & & \\
$\begin{array}{l}\text { (RLU\%) erythrocyte-P } \\
\text { (RLU\%) erythrocyte-Sr } \\
\text { vitamin } \mathrm{D}_{3} \text { level-B } \\
\text { vitamin } \mathrm{D}_{3} \text { level-Mn }\end{array}$ & -0.755 & & -0.767 & \\
\hline
\end{tabular}


the vitamin $\mathrm{D}_{3}$ level and metal concentrations in the vitamin $\mathrm{D}_{3}$ treated patient control group and the vitamin $\mathrm{D}_{3}$ treated cancerous group (Table 6). In the vitamin $\mathrm{D}_{3}$ treated patient control group the vitamin $\mathrm{D}_{3}$ level correlated in a significantly positive way with B level $(+0.821)$ and in the vitamin $D_{3}$ treated cancerous group the vitamin $D_{3}$ level correlated in a significantly positive way with the Mn level $(+0.829)$. In the other groups, there were no significant correlations between the metal elements and the vitamin $\mathrm{D}_{3}$ level.

We looked at correlations of the metal elements, the redox parameters and the PSA (Table 6). The correlations in the vitamin $\mathrm{D}_{3}$ treated groups are different to the correlations found in the control. We can come to the conclusion that the vitamin $\mathrm{D}_{3}$ treatment obviously had an effect on the metal element- and the redox-homeostasis. In the high-risk prostate cancer group with vitamin $\mathrm{D}_{3}$ treatment, there was no correlation found, that can be by reason of a total homeostasis disorder. It is not reflected on the metal elements but can be generated by a largescale change of the redox parameters. The positive correlation between PSA and Fe suggests that the high Fe level could assist the increase of PSA level.

\section{Conclusion}

According to our experiment vitamin $\mathrm{D}_{3}$ plays an essential role in the inorganic elements level that can indicate its influence on the element metabolism in prostate cancer. The metal element concentration difference can further influence the overcome the disease. In the erythrocyte of patients with prostate cancer, the vitamin $\mathrm{D}_{3}$ treatment had a positive effect on the metabolism of the most important essential elements as $\mathrm{Ca}, \mathrm{Cu}, \mathrm{Mn}, \mathrm{Mg}$ and $\mathrm{Ni}$ because their concentration converged to the control values. At the same time, the potential formation of Li deficiency by the treatment of vitamin $\mathrm{D}_{3}$ in prostate cancer needs further investigation.

From the induced chemiluminescence and H-donating ability results, it appears that the vitamin $\mathrm{D}_{3}$ treatment favorably affected the antioxidant system because we got consistently better results in the patient control and cancerous groups. It is worth considering from our results that, the difference was more expressed in the high-risk cancerous group with vitamin $\mathrm{D}_{3}$.

There is still no existing optimal factor for the prognosis of prostate cancer. Therefore our results could be one further step to the feasible diagnosis of prostate cancer. Besides, metal element status could be another prognostic index in prostate adenocarcinoma to differentiate between low and high-risk estate cancer's progression phases. The significant decrease of PSA with the increase of the scavenging capacity of the treatment might be attributable to the beneficial effect of vitamin $\mathrm{D}_{3}$ on the antioxidant system. However, further comprehensive investigations are required to understand the role of vitamin $D_{3}$ on the element status in prostate adenocarcinoma.

\section{Role of funding source}

Funding for the study was provided by the $3 / 1 \mathrm{Ph} . \mathrm{D}$. program of Semmelweis University.

Conflict of interest

Authors declare that they have no conflict of interest.

\section{Acknowledgement}

Authors express their thanks to Dr. Károly Héberger for his scientific advice in the statistical analysis and Mrs. Györgyi Tóth for her assistance with the patients. The labor diagnostic measurements were performed by Synlab Hungary Kft.

\section{References}

[1] Y. Dhas, N. Mishra, J. Banerjee, Vitamin D deficiency and oxidative stress in type 2 diabetic population of India, Cardiovasc. Hematol. Agents Med. Chem. 14 (2016) 82-89.

[2] M. Aguirre, N. Manzano, Y. Salas, M. Angel, F.A. Diaz-Couselo, M. Zylberman, Vitamin D deficiency in patients admitted to the general ward with breast, lung, and colorectal cancer in Buenos Aires, Argentina, Arch Osteoporos. 11 (2016) 4.

[3] J. Riedel, L. Straub, J. Wissing, A. Artmann, M. Schmidmayr, M. Kiechle, V.R. Seifert-Klauss, Vitamin D and mammographic findings, Geburtshilfe Frauenheilkd 76 (2016) 570-578.

[4] K.K. Deeb, D.L. Trump, C.S. Johnson, Vitamin D signaling pathways in cancer: potential for anticancer therapeutics, Nat. Rev. Cancer 7 (2007) 684-700.

[5] T.C. Chen, M.F. Holick, Vitamin D and prostate cancer prevention and treatment, Trends Endocrinol. Metab. 14 (2003) 423-430.

[6] L.P. Freedman, Multimeric coactivator complexes for steroid/nuclear receptors, Trends Endocrinol. Metab. 10 (1999) 403-407.

[7] S.A. Swami, A.V. Krishnan, D. Feldman, Vitamin D metabolism and action in the prostate: implications for health and disease, Mol. Cell. Endocrinol. 347 (2011) 61-69.

[8] I.S. Mathiasen, U. Lademann, M. Jaattela, Apoptosis induced by vitamin D compounds in breast cancer cells is inhibited by Bcl-2 but does not involve known caspases or p53, Cancer Res. 59 (1999) 4848-4856.

[9] M. Jenab, H.B. Bueno-de-Mesquita, P. Ferrari, F.J. van Duijnhoven, T. Norat, T. Pischon, E.H. Jansen, N. Slimani, G. Byrnes, S. Rinaldi, A. Tjonneland, A. Olsen, K. Overvad, M.C. Boutron-Ruault, F. Clavel-Chapelon, S. Morois, R. Kaaks, J. Linseisen, H. Boeing, M.M. Bergmann, A. Trichopoulou, G. Misirli, D. Trichopoulos, F. Berrino, P. Vineis, S. Panico, D. Palli, R. Tumino, M.M. Ros, C.H. van Gils, P.H. Peeters, M. Brustad, E. Lund, M.J. Tormo, E. Ardanaz, L. Rodriguez, M.J. Sanchez, M. Dorronsoro, C.A. Gonzalez, G. Hallmans, R. Palmqvist, A. Roddam, T.J. Key, K.T. Khaw, P. Autier, P. Hainaut, E. Riboli, Association between pre-diagnostic circulating vitamin D concentration and risk of colorectal cancer in European populations: a nested case-control study, BMJ 340 (2010) b5500.

[10] M.Y. Wei, C.F. Garland, E.D. Gorham, S.B. Mohr, E. Giovannucci, Vitamin D and prevention of colorectal adenoma: a meta-analysis, Cancer Epidemiol Biomarkers Prev. 17 (2008) 2958-2969.

[11] R.J. Skowronski, D.M. Peehl, D. Feldman, Vitamin D and prostate cancer: 1,25 dihydroxyvitamin D3 receptors and actions in human prostate cancer cell lines, Endocrinology 132 (1993) 1952-1960.

[12] E. Munetsuna, A. Kittaka, T.C. Chen, T. Sakaki, Metabolism and action of 25-hydroxy-19-nor-vitamin D(3) in human prostate cells, Vitam. Horm. 100 (2016) $357-377$.

[13] S.Y. Rhieu, A.J. Annalora, E. LaPorta, J. Welsh, T. Itoh, K. Yamamoto, T. Sakaki, T.C. Chen, M.R. Uskokovic, G.S. Reddy, Potent antiproliferative effects of 25-hydroxy-16-ene-23-yne-vitamin $\mathrm{D}(3)$ that resists the catalytic activity of both CYP27B1 and CYP24A1, J. Cell. Biochem. 115 (2014) 1392-1402.

[14] S. Swami, A.V. Krishnan, J.Y. Wang, K. Jensen, R. Horst, M.A. Albertelli, D. Feldman, Dietary vitamin $\mathrm{D}(3)$ and 1,25-dihydroxyvitamin $\mathrm{D}(3)$ (calcitriol) exhibit equivalent anticancer activity in mouse xenograft models of breast and prostate cancer, Endocrinology 153 (2012) 2576-2587.

[15] A.V. Krishnan, D.M. Peehl, D. Feldman, The role of vitamin D in prostate cancer, Vitamin D Analogs in Cancer Prevention and Therapy, Springer, 2003, pp. 205-221.

[16] M.T. Ling, X.-S. Wang, X. Fau-Ouyang, T.K.W. Ouyang, X.S. Fau-Lee, T.-Y. Lee, T.K. Fau-Fan, K. Fan, T.Y. Fau-Xu, S.-W. Xu, K. Fau-Tsao, Y.C. Tsao, S.W. Fau-Wong, Y.C. Wong, Activation of MAPK signaling pathway is essential for Id-1 induced serum independent prostate cancer cell growth, Oncogene. 21 (2002) 8498-8505.

[17] B.M. Fau, G.R. Thomson-Mundy, T.J. Mundy, G.R. Fau-Chambers, T.J. Chambers, Tumor necrosis factors alpha and beta induce osteoblastic cells to stimulate osteoclastic bone resorption, J. Immunol. 138 (1987) 775-779.

[18] A. Blázovics, P. Nyirády, G. Bekõ, E. Székely, Á. Szilvás, E. Kovács-Nagy, A. Horváth, M. Szúcs, I. Romics, É. Sárdi, Changes in erythrocyte transmethylation ability are predictive factors for tumor prognosis in prostate cancer, Croatica Chemica Acta. 84 (2011) 127-131.

[19] S.B. Baylin, J.G. Herman, J.R. Graff, P.M. Vertino, J.P. Issa, Alterations in DNA methylation: a fundamental aspect of neoplasia, Adv. Cancer Res. 72 (1998) 141-196.

[20] A. Blazovics, Redox homeostasis, bioactive agents and transduction therapy, Curr. Signal Transduct. Ther. 2 (2007) 226-239.

[21] G.K. Schwalfenberg, S.J. Genuis, Vitamin D, essential minerals, and toxic elements: exploring interactions between nutrients and toxicants in clinical medicine, Sci. World J. (2015) (2015) 318595.

[22] F.W. Kemp, P.V. Neti, R.W. Howell, P. Wenger, D.B. Louria, J.D. Bogden, Elevated blood lead concentrations and vitamin D deficiency in winter and summer in young urban children, Environ. Health Perspect. (2007) 630-635.

[23] B.P. Singh, S. Dwivedi, U. Dhakad, R.C. Murthy, V.K. Choubey, A. Goel, S.N. Sankhwar, Status and interrelationship of zinc, copper, iron, calcium and selenium in prostate cancer, Indian J. Clin. Biochem. 31 (2016) 50-56.

[24] G. Erdei, V.A. Kovács, M. Bakacs, É. Martos, Országos Táplálkozás és Tápláltsági Állapot Vizsgálat 2014. I. A magyar felnőtt lakosság Tápláltsági állapota, Orvosi Hetilap 158 (2017) 533-540.

[25] M.-C. Chapuy, P. Preziosi, M. Maamer, S. Arnaud, P. Galan, S. Hercberg, P. Meunier, Prevalence of vitamin D insufficiency in an adult normal population, Osteoporos. Int. 7 (1997) 439-443.

[26] R. Vieth, P.C. Chan, G.D. MacFarlane, Efficacy and safety of vitamin D3 intake exceeding the lowest observed adverse effect level, Am. J. Clin. Nutr. 73 (2001) 288-294.

[27] T. Hatano, H. Kagawa, T. Yasuhara, T. Okuda, Two new flavonoids and other constituents in licorice root: their relative astringency and radical scavenging 
effects, Chem. Pharm. Bull. 36 (1988) 2090-2097.

[28] A. Blázovics, A. Kovács, A. Lugasi, K. Hagymási, L. Bíró, J. Fehér, Antioxidant defense in erythrocytes and plasma of patients with active and quiescent Crohn disease and ulcerative colitis: a chemiluminescent study, Clin. Chem. 45 (1999) 895-896.

[29] A. Blazovics, A. Kovacs, A. Lugasi, K. Hagymasi, L. Biro, J. Feher, Antioxidant defense in erythrocytes and plasma of patients with active and quiescent Crohn disease and ulcerative colitis: a chemiluminescent study, Clin. Chem. 45 (1999) 895-896.

[30] K. Szentmihalyi, Z. May, G. Szenasi, C. Mathe, A. Sebesteny, M. Albert, A. Blazovics, Cisplatin administration influences on toxic and non-essential element metabolism in rats, J. Trace Elem. Med. Biol. 28 (2014) 317-321.

[31] S.E. Blutt, N.L. Weigel, Vitamin D and prostate cancer, Proc. Soc. Exp. Biol. Med 221 (1999) 89-98.

[32] D. Feldman, R.J. Skowronski, D.M. Peehl, Vitamin D and prostate cancer, Diet Cancer 354 (1995) 53-63.

[33] P. Nyirady, E. Sardi, G. Beko, M. Szucs, A. Horvath, E. Szekely, K. Szentmihalyi, I. Romics, A. Blazovics, Effects of bioactive molecules of Beta vulgaris L. ssp. esculenta var. rubra on metastatic prostate cancer, Orv Hetil 151 (2010) 1495-1503.

[34] R.L. Horst, J.P. Goff, T.A. Reinhardt, Role of vitamin D in calcium homeostasis and its use in prevention of bovine periparturient paresis, Acta Vet. Scand. Suppl. 97 (2003) 35-50.

[35] P. Lips, Interaction between vitamin D and calcium, Scand. J. Clin. Lab Invest. Suppl. 243 (2012) 60-64.

[36] V. Lemaire, F.L. Tobin, L.D. Greller, C.R. Cho, L.J. Suva, Modeling the interactions between osteoblast and osteoclast activities in bone remodeling, J. Theor. Biol. 229 (2004) 293-309.

[37] J.G. Pounds, Effect of lead intoxication on calcium homeostasis and calciummediated cell function: a review, Neurotoxicology 5 (1984) 295-331.

[38] C.S. Fullmer, Lead-calcium interactions: involvement of 1, 25-dihydroxyvitamin D, Environ. Res. 72 (1997) 45-55.

[39] M. Sorrell, J.F. Rosen, Interactions of lead, calcium, vitamin D, and nutrition in lead-burdened children, Arch. Environ. Health 32 (1977) 160-164.

[40] J. Bressler, K.-a. Kim, T. Chakraborti, G. Goldstein, Molecular mechanisms of lead neurotoxicity, Neurochem. Res. 24 (1999) 595-600.

[41] S.S. Leonard, G.K. Harris, X. Shi, Metal-induced oxidative stress and signal transduction, Free Radical Biol. Med. 37 (2004) 1921-1942.

[42] K. Salnikow, A. Zhitkovich, Genetic and epigenetic mechanisms in metal carcinogenesis and cocarcinogenesis: nickel, arsenic, and chromium, Chem. Res. Toxicol. 21 (2008) 28-44.

[43] H. Tapiero, K.D. Tew, Trace elements in human physiology and pathology: zinc and metallothionein, Biomed. Pharmacother. 57 (2003) 399-411.

[44] Y.J. Suzuki, H.J. Forman, A. Sevanian, Oxidants as stimulators of signal transduction, Free Radical Biol. Med. 22 (1997) 269-285.

[45] M. Aapro, A. Osterborg, P. Gascon, H. Ludwig, Y. Beguin, Prevalence and management of cancer-related anemia, iron deficiency and the specific role of i.v. iron, Ann. Oncol. 23 (2012) 1954-1962.

[46] B. Sooragonda, S.K. Bhadada, V.N. Shah, P. Malhotra, J. Ahluwalia, N. Sachdeva, Effect of vitamin D replacement on hemoglobin concentration in subjects with concurrent iron-deficiency anemia and vitamin D deficiency: a randomized, singleblinded, placebo-controlled trial, Acta Haematol. 133 (2015) 31-35.

[47] L.C. Costello, R.B. Franklin, Novel role of zinc in the regulation of prostate citrate metabolism and its implications in prostate cancer, Prostate 25 (1998) 285-296.

[48] X. Gomez, F. Arocha, F. Espinoza, D. Fernandez, A. Vasquez, V. Granadillo, Zinc levels in prostatic fluid of patients with prostate pathologies, Invest. Clin. 48 (2007) 287-294.

[49] E.A. Platz, K.J. Helzlsouer, Selenium, zinc, and prostate cancer, Epidemiol Rev. 23 (2001) 93-101.

[50] A.H. Shankar, A.S. Prasad, Zinc and immune function: the biological basis of altered resistance to infection, Am. J. Clin. Nutr. 68 (1998) 447S-463S.

[51] A. Blázovics, P. Nyirády, I. Romics, M. Szúcs, A. Horváth, Á. Szilvás, E. Székely, K. Szentmihályi, G. Bekő, É. Sárdi, How can cancer-associated anemia be moderated with nutritional factors and how do beta Vulgaris L. Ssp. Esculenta var. Rubra modify the transmethylation reaction in erythrocytes, in: Donald S. Silverberg (Ed.), Cancerous Patients, InTech Open Access Publisher, Anemia, Rijeka, 2012, pp. 93-114.

[52] W.T. Cefalu, F.B. Hu, Role of chromium in human health and diabetes, Diabetes Care 27 (2004) 2741-2751.

[53] G. Singh, C.L. Lakkis, R. Laucirica, D.E. Epner, Regulation of prostate cancer cell division by glucose, J. Cell. Physiol. 180 (1999) 431-438.

[54] A. Hartwig, L.H. Mullenders, R. Schlepegrell, U. Kasten, D. Beyersmann, Nickel(II) interferes with the incision step in nucleotide excision repair in mammalian cells, Cancer Res. 54 (1994) 4045-4051.

[55] R.B. Meintzer, H. Steenbock, Vitamin D and magnesium absorption, J. Nutr. 56 (1955) 285-294.

[56] A. Zittermann, Magnesium deficit-overlooked cause of low vitamin D status? BMC Med. 11 (2013) 1.

[57] K.S. Kasprzak, M.P. Waalkes, L.A. Poirier, Antagonism by essential divalent metals and amino acids of nickel(II)-DNA binding in vitro, Toxicol. Appl. Pharmacol. 82 (1986) 336-343.

[58] K. Mlyniec, C.L. Davies, I.G. de Aguero Sanchez, K. Pytka, B. Budziszewska, G. Nowak, Essential elements in depression and anxiety. Part I, Pharmacol. Rep. 66 (2014) 534-544.

[59] G.S. Malhi, M. Tanious, P. Das, C.M. Coulston, M. Berk, Potential mechanisms of action of lithium in bipolar disorder, Curr. Underst., CNS Drugs 27 (2013) 135-153.

[60] A. Sun, I. Shanmugam, J. Song, P.F. Terranova, J.B. Thrasher, B. Li, Lithium suppresses cell proliferation by interrupting E2F-DNA interaction and subsequently reducing S-phase gene expression in prostate cancer, Prostate 67 (2007) 976-988.

[61] A. Blazovics, A. Szilvas, G. Szekely, E. Tordai, E. Szekely, G. Czabai, Z. Pallai, E. Sardi, Important bioactive molecules of erythrocytes in colorectal cancer patients after colectomy, Open Med. Chem. J. 2 (2008) 6-10.

[62] E. Garcion, L. Sindji, G. Leblondel, P. Brachet, F. Darcy, 1, 25-Dihydroxyvitamin D3 regulates the synthesis of $\gamma$-glutamyl transpeptidase and glutathione levels in rat primary astrocytes, J. Neurochem. 73 (1999) 859-866.

[63] B.Y. Bao, H.J. Ting, J.W. Hsu, Y.F. Lee, Protective role of 1a, 25-dihydroxyvitamin $\mathrm{D}_{3}$ against oxidative stress in nonmalignant human prostate epithelial cells, Int. J. Cancer 122 (2008) 2699-2706. 